\title{
Nomogram Uroflowmetri pada Anak-anak Usia 6-14 Tahun di Wilayah Jakarta dan Sekitarnya
}

\author{
Hani A. Hendarto, Arry Rodjani, Chaidir A. Mochtar
}

ARTIKEL

ASLI

\begin{abstract}
Abstrak
Pendahuluan : Pola perilaku berkemih pada anak-anak berbeda dengan orang dewasa, sehingga diperlukan untuk mendapatkan nilai referensi normal uroflowmetri pada anak-anak usia 6-14 tahun.

Metode : Dilakukan uroflowmetri pada sejumlah 209 anak-anak tanpa gangguan urologis, neurologis, dan/atau psikologis usia 6-14 tahun. Dicatat nilai pancaran maksimum, nilai pancaran rata-rata, volume urin selain data demografik berupa usia, jenis kelamin, berat, dan tinggi badan serta penghitungan body surface area dan body mass index. Data statistik menggunakan SPSS, dan disusun nomogram menggunakan program Base Maker Excel.

Hasil : Rerata Q max pada perempuan adalah $14,99 \pm 5,51 \mathrm{ml} /$ det dan pada laki-laki $14,45 \pm 7,21 \mathrm{ml} /$ det sedangkan rerata Q average (ave) pada perempuan adalah 8,75 $\pm 3,25 \mathrm{ml} / \mathrm{det}$ dan pada laki-laki $8,74 \pm 3,95 \mathrm{ml} /$ det. Perbedaan rerata $\mathrm{Q}$ max dan $\mathrm{Q}$ ave pada kedua jenis kelamin relatif kecil yaitu masing-masing $0,54 \mathrm{ml} / \mathrm{det}$ dan $0,01 \mathrm{ml} / \mathrm{det}$. Rerata voided volume pada perempuan adalah $115,04 \pm 60,19 \mathrm{ml}$ dan pada lakilaki 100,78 $\pm 82,44 \mathrm{ml}$. Pada anak laki-laki terdapat hubungan bermakna antara penambahan tinggi badan, berat badan, body surface area, dan body mass index terhadap Q max. Demikian pula dengan Q ave kecuali untuk body mass index. Untuk voided volume, semuanya tidak bermakna. Peningkatan Q max maupun Q ave, masih dipengaruhi oleh usia. Sedangkan untuk anak perempuan, tidak terdapat hubungan bermakna antara $\mathrm{Q}$ max, $\mathrm{Q}$ ave dan voided volume dengan tinggi badan, berat badan, body surface area, dan body mass index. Tinggi rendahnya $\mathrm{Q}$ max dan $\mathrm{Q}$ ave, tidak dipengaruhi oleh usia. Baik pada anak laki-laki maupun anak perempuan, $\mathrm{Q}$ max dan $\mathrm{Q}$ ave mempunyai hubungan bermakna dengan voided volume. Kemudian dibuat nomogram untuk $\mathrm{Q} \max$ dan $\mathrm{Q}$ ave dengan persamaan garis $\mathrm{y}=$ konstanta $\log (\mathrm{usia})+$ konstanta untuk persentil 10,25,40,70, dan 90 .
\end{abstract}

Diskusi : Penelitian ini memberikan nilai referensi untuk nilai pancaran maksimum dan nilai pancaran rata-rata urin pada anak-anak laki-laki dan perempuan normal. Walaupun demikian masih diperlukan penelitian lanjutan dengan jumlah sampel yang lebih banyak

Kata kunci : anak-anak, nomogram, uroflowmetri. (J I Bedah Indones. 2007; 35(2): 58-64).

\section{Uroflowmetry Nomograms of Jakarta Children Aged 6-14 Years}

\begin{abstract}
Introduction : As the voiding habits of children differs from adult people, we aimed to establish normal reference values of urinary flow rates in children between 6 to 14 years of age.

Methods : Two hundreds and nine uroflowmetry studies were performed on children with no history of renal, urological, psychological nor neurological disorder between the ages 6 and 14. The voiding volume, maximum and average flow rates were extensively analyzed, as well as age, sex, body weight, height, BSA and BMI. Statistical analysis was performed using SPSS 13.0 and Base Maker Excel for nomogram construction

Results : In boys, $Q$ max showed close association with body weight, height, BSA and BMI, as well as Q average (ave), with exception for BMI. There was no association between weight, height, BSA and BMI with voided volume. There was significant increase in $Q$ max and $Q$ ave with increasing age. In both groups, $Q$ max and $Q$ ave had close association with voided volume. The $Q$ max and $Q$ ave nomograms were plotted for both girls and boys separately. We constructed nomograms for $Q$ max and $Q$ ave with linear equivalency $y=\operatorname{constant} \log ($ age $)+$ constant for percentile 10,25,40,70 and 90

Discussion : These nomograms provide normal values in both sexes for $Q$ max and $Q$ ave. A further study involve bigger sample size recommended.
\end{abstract}

Keywords : children, nomograms, uroflowmetry. (J I Bedah Indones. 2007; 35(2): 58-64)

Departemen Urologi

RS Cipto Mangunkusumo, Jakarta

(Fakultas Kedokteran Universitas Indonesia) 


\section{PENDAHULUAN}

Pola perilaku berkemih pada anak-anak berbeda dengan orang dewasa, sehingga perlu untuk mendapatkan nilai referensi normal pada uroflowmetri pada anak-anak usia 6-14 tahun. Uroflowmetri merupakan salah satu bentuk uji urodinamik sederhana yang paling sering dilakukan, uroflowmetri merupakan pengukuran pancaran urin yang mudah dilakukan dan tidak invasif. Uroflowmetri sendiri tidak dapat mendeterminasi kausa disfungsi berkemih, tetapi sangat berguna dalam seleksi pasien untuk uji urodinamik yang lebih kompleks. Uroflowmetri juga membantu dalam mendeterminasi respon pengobatan pada keadaan patologis tertentu.

Pengukuran uroflowmetri pada anak-anak pertama dilakukan oleh Kaufman pada tahun 1957. Nilai normal yang direkomendasikan adalah 15-20 ml/det pada laki-laki, dan $12-20 \mathrm{ml} / \mathrm{det}$. Siroky dkk. mengkonstruksikan nomogram menggunakan data dari grup dalam jumlah kecil dari lelaki muda, dan nomogram Jorgensen dkk. dikhususkan untuk perempuan dewasa. Semua nomogram tersebut dibuat untuk pasien dewasa. Nomogram untuk anak-anak yang pernah dibuat adalah nomogram Miskole, dengan buli-buli dalam keadaan penuh, rerata pancaran urin adalah $16 \mathrm{ml} / \mathrm{det}$ pada anak perempuan, dan $14 \mathrm{ml} /$ det pada anak laki-laki.

Upaya penentuan nilai referensi normal pada pancaran urin membutuhkan data gambaran sebenarnya pada anak-anak baik laki-laki maupun perempuan. Secara teknis, data pasti saat ini masih kurang, selain kesulitan penentuan nilai normal pada anak-anak karena proses perkembangan yang bersifat dinamis dan bervariasi pada masing-masing anak-anak .

Penelitian ini dimaksudkan untuk mengetahui nilai referensi normal pada anak-anak baik laki-laki maupun perempuan dari flow maksimum dan rerata di Jakarta, karena belum pernah ada nomogram uroflowmetri untuk anak-anak, dan kebanyakan software pada uroflowmetri menggunakan nomogram orang dewasa. Nomogram dikonstruksikan untuk mengetahui nilai referensi normal pada kedua jenis kelamin untuk pancaran urin, dengan varian voided volume dalam bentuk centile.

Pada akhir penelitian diharapkan dapat diperoleh data nilai pancaran urin pada anak-anak untuk kemudian disusun suatu nomogram uroflowmetri khusus untuk anak-anak. Manfaat yang diharapkan dari penelitian ini adalah tersedianya nomogram sebagai data dasar yang diharapkan dapat menjadi salah satu bahan acuan ahli urologi dalam tatalaksana klinis, khususnya pada anak-anak.

\section{METODE}

Studi cross-sectional dilakukan pada bulan September sampai dengan Oktober 2007 pada 209 anak-anak usia 614 tahun di wilayah Jakarta dan sekitanya. Studi ini telah mendapat persetujuan dari Panitia Tetap Penilai Etik Penelitian Kedokteran Fakultas Kedokteran Universitas Indonesia. Sampling diambil dari beberapa sekolah selain anak-anak pengunjung di RS Cipto Mangunkusumo (RSCM).
Para orangtua murid serta guru telah mendapat penjelasan sebelumnya mengenai metode penelitian dan pemeriksaan, dijelaskan pula bahwa penelitian ini tidak bersifat invasif dan tidak menyakiti anak-anak. Anak-anak secara sukarela mengikuti penelitian, dan orangtua /wali anak yang bersangkutan menandatangani surat persetujuan.

Jumlah sampel dihitung menurut rumus sebagai berikut :

$$
\mathrm{n}=\frac{\mathrm{Z} \alpha^{2} \mathrm{pq}}{\mathrm{L} 2}
$$

( $\mathrm{n}=$ jumlah sampel awal, $\mathrm{p}=$ persentase anak-anak usia 6-14 tahun dengan pancaran urin normal, $\mathrm{L}=$ kesalahan yang diperkenankan, sebesar $5 \%, Z \alpha=$ derajat suatu batas kepercayaan, dengan nilai $\alpha=0,05 ; Z \alpha=1,96, q=1-p)$

Dengan perhitungan di atas didapatkan 200 sampel anakanak.

Uroflowmetri dilakukan pada 251 anak-anak tanpa kelainan ginjal, urologis, psikologis dan/atau neurologis. Partisipan diinstruksikan untuk datang ke sekolah atau rumah sakit dengan keadaan buli-buli penuh. Digunakan uroflowmetri yang diletakkan dalam toilet tertutup dengan didampingi dokter/perawat dalam pengambilan sampling. Anak-anak berkemih sesuai instruksi, pada saat sensasi maksimum buli-buli penuh. Sejumlah 42 anak masuk dalam kriteria eksklusi karena voided volume kurang dari $20 \mathrm{ml}$. Dicatat nilai pancaran maksimum $(Q \max )$, nilai pancaran rata-rata ( $Q$ ave), voided volume (VV), waktu pencapaian pancaran maksimum, flow time dan voiding time, selain data demografis dasar berupa berupa usia, jenis kelamin, berat dan tinggi badan serta penghitungan body surface area dan body mass index.

Dilakukan analisis statistik menggunakan program SPSS 13.0, dengan $p$ value $<0,05$ untuk nilai signifikansi. Digunakan metode regresi quintile untuk menemukan level persentil $(10,25,40,70,90)$. Kemudian disusun nomogram untuk anak-anak laki-laki dan perempuan secara terpisah menggunakan program Base Maker Excel.

\section{HASIL}

Dilakukan uroflowmetri pada 209 anak-anak usia 6-14 tahun, 106 laki-laki $(50,72 \%)$ dan 103 perempuan $(49,28$ $\%$ ).

Tabel 1. Sebaran usia berdasarkan jenis kelamin

\begin{tabular}{ccccrr}
\hline \multirow{2}{*}{$\begin{array}{c}\text { Usia } \\
\text { (tahun) }\end{array}$} & \multicolumn{2}{c}{ Laki-laki } & \multicolumn{2}{c}{ Perempuan } & \multirow{2}{*}{ Total } \\
\cline { 2 - 4 } & $\mathrm{N}$ & \multicolumn{1}{c}{$\%$} & $\mathrm{n}$ & \multicolumn{1}{c}{$\%$} & \\
\hline 6 & 14 & 13,2 & 9 & 8,7 & 23 \\
7 & 11 & 10,4 & 14 & 13,6 & 25 \\
8 & 5 & 4,7 & 8 & 7,8 & 13 \\
9 & 15 & 14,2 & 15 & 14,6 & 30 \\
10 & 12 & 11,3 & 20 & 19,4 & 32 \\
11 & 21 & 19,8 & 14 & 13.6 & 35 \\
12 & 13 & 12,3 & 10 & 9,7 & 23 \\
13 & 8 & 7,5 & 10 & 9,7 & 18 \\
14 & 7 & 6,6 & 3 & 2,9 & 10 \\
& 106 & 100,0 & 103 & 100,0 & 209 \\
\hline
\end{tabular}


Tabel 2. Nilai rerata dan standar deviasi berdasarkan jenis kelamin

\begin{tabular}{|c|c|c|c|c|c|}
\hline \multirow{2}{*}{ Variabel } & \multicolumn{2}{|c|}{ Mean } & \multicolumn{2}{|c|}{ Mean } & \multirow{2}{*}{$p$} \\
\hline & Mean & Std & Mean & $\bar{S} t d$ & \\
\hline Usia & 9,86 & 2,42 & 9,68 & 2,21 & 0,577 \\
\hline Voided volume & 100,78 & 82,44 & 115,04 & 60,19 & 0,156 \\
\hline $\mathrm{Q}_{\max }$ & 14,45 & 7,21 & 14,99 & 5,51 & 0,542 \\
\hline $\mathrm{Q}_{\text {average }}$ & 8,74 & 3,95 & 8,75 & 3,25 & 0,992 \\
\hline Berat Badan & 30,01 & 11,12 & 30,34 & 9,01 & 0,814 \\
\hline Tinggi Badan & 130,50 & 14,05 & 132,36 & 13,32 & 0,326 \\
\hline BSA & 1,035 & 0,229 & 1,053 & 0,196 & 0,150 \\
\hline BMI & 17,167 & 4,028 & 17,107 & 3,492 & 0,908 \\
\hline
\end{tabular}

$\mathrm{BSA}=$ body surface area

$\mathrm{BMI}=$ body mass index

Tabel 3. Nilai rerata dan standar deviasi $Q \max , Q$ ave, dan voided volume berdasarkan umur pada anak laki-laki

\begin{tabular}{|c|c|c|c|c|c|c|c|}
\hline \multirow{2}{*}{$\begin{array}{c}\text { Usia } \\
\text { (tahun) }\end{array}$} & \multirow{2}{*}{$\mathrm{n}$} & \multicolumn{2}{|c|}{$Q \max$} & \multicolumn{2}{|c|}{$Q$ ave } & \multicolumn{2}{|c|}{ Voided volume } \\
\hline & & Mean & Std & Mean & Std & Mean & Std \\
\hline 6 & 14 & 12,36 & 0,921 & 8,79 & 1,050 & 95,07 & 12,456 \\
\hline 7 & 11 & 12,62 & 1,222 & 7,77 & 0,680 & 81,36 & 22,596 \\
\hline 8 & 5 & 16,06 & 3,807 & 7,78 & 1,847 & 76,00 & 18,647 \\
\hline 9 & 15 & 10,00 & 0,661 & 6,13 & 0,403 & 85,27 & 10,781 \\
\hline 10 & 12 & 13,56 & 1,586 & 8,76 & 1,161 & 85,08 & 16,759 \\
\hline 11 & 21 & 14,77 & 2,139 & 8,05 & 0,846 & 103,81 & 30,031 \\
\hline 12 & 13 & 16,45 & 1,206 & 10,24 & 0,869 & 107,00 & 18,151 \\
\hline 13 & 8 & 13,81 & 1,367 & 9,33 & 0,785 & 133,50 & 23,366 \\
\hline 14 & 7 & 27,40 & 3,503 & 15,09 & 2,272 & 162,57 & 34,440 \\
\hline & 106 & 14,45 & 0,700 & 8,743 & 0,384 & 100,70 & 8,007 \\
\hline
\end{tabular}

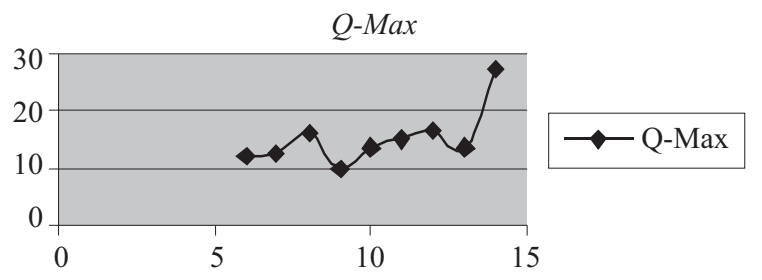

Usia - laki-laki

Gambar 1. Rerata Q max pada masing-masing kelompok usia pada anak laki-laki

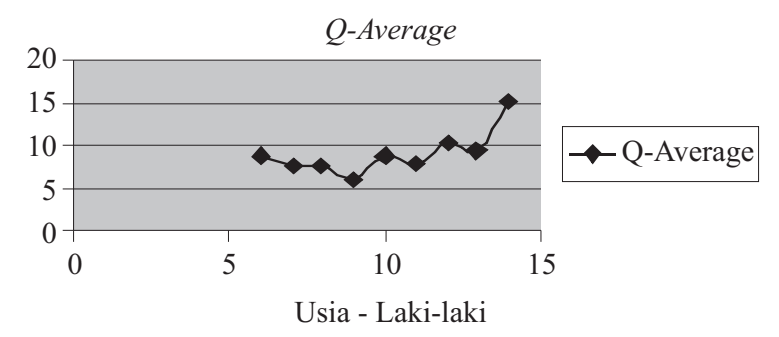

Gambar 2. Rerata $Q$ ave pada masing-masing kelompok usia pada anak laki-laki

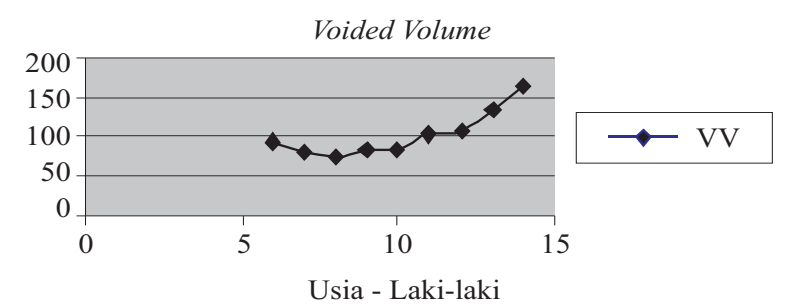

Gambar 3. Rerata voided volume pada masing-masing kelompok usia pada anak laki-laki 
Pada anak laki-laki terdapat hubungan bermakna antara penambahan tinggi badan, berat badan, body surface area, dan body mass index terhadap $Q$ max. Demikian pula dengan Qave kecuali untuk body mass index. Untuk voided volume, semuanya tidak bermakna. Peningkatan $Q \max$ maupun $Q$ ave, masih dipengaruhi oleh usia dan voided volume.

Sedangkan untuk anak perempuan, tidak terdapat hubungan bermakna antara $Q \max , Q$ ave, dan voided volume dengan tinggi badan, berat badan, body surface area, dan body mass index. Tinggi rendahnya $Q \max$ dan $Q$ ave, tidak dipengaruhi oleh usia pada anak laki-laki maupun anak perempuan, $Q$ max dan $Q$ ave mempunyai hubungan bermakna dengan voided volume.

Tabel 4. Nilai rerata $Q \max , Q$ ave, dan voided volume berdasarkan umur pada anak perempuan

\begin{tabular}{|c|c|c|c|c|c|c|c|}
\hline \multirow{2}{*}{$\begin{array}{c}\text { Usia } \\
\text { (tahun) }\end{array}$} & \multirow[b]{2}{*}{$\mathrm{n}$} & \multicolumn{2}{|c|}{$Q \max$} & \multicolumn{2}{|c|}{$Q$ ave } & \multicolumn{2}{|c|}{ Voided volume } \\
\hline & & Mean & Std & Mean & Std & Mean & Std \\
\hline 6 & 9 & 15,23 & 2,115 & 9,36 & 0,782 & 116,11 & 12,456 \\
\hline 7 & 14 & 14,66 & 1,076 & 8,03 & 0,571 & 85,64 & 22,596 \\
\hline 8 & 8 & 12,59 & 1,805 & 6,925 & 1,056 & 108,75 & 18,647 \\
\hline 9 & 15 & 16,47 & 0,667 & 9,727 & 0,602 & 117,60 & 10,781 \\
\hline 10 & 20 & 15,35 & 1,773 & 9,530 & 1,115 & 135,85 & 16,759 \\
\hline 11 & 14 & 13,14 & 0,785 & 7,871 & 0,642 & 111,79 & 30,031 \\
\hline 12 & 10 & 17,13 & 1,705 & 9,110 & 0,789 & 128,90 & 18,151 \\
\hline 13 & 10 & 15,97 & 2,289 & 9,390 & 1,130 & 116,30 & 23,366 \\
\hline 14 & 3 & 10,53 & 0,769 & 5,800 & 1,172 & 79,00 & 34,440 \\
\hline & 103 & 14,99 & 0,543 & 8,749 & 0,3198 & 115,04 & 8,007 \\
\hline
\end{tabular}

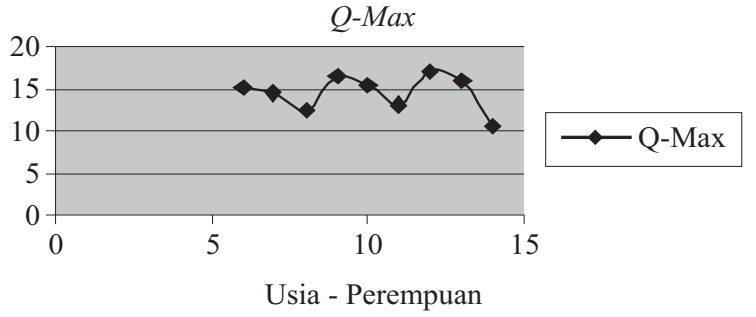

Gambar 4. Rerata $Q \max$ pada masing-masing kelompok usia pada anak perempuan

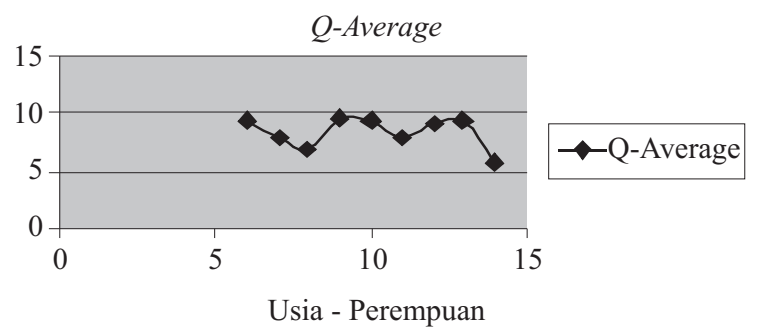

Gambar 5. Rerata $Q$ ave pada masing-masing kelompok usia pada anak perempuan

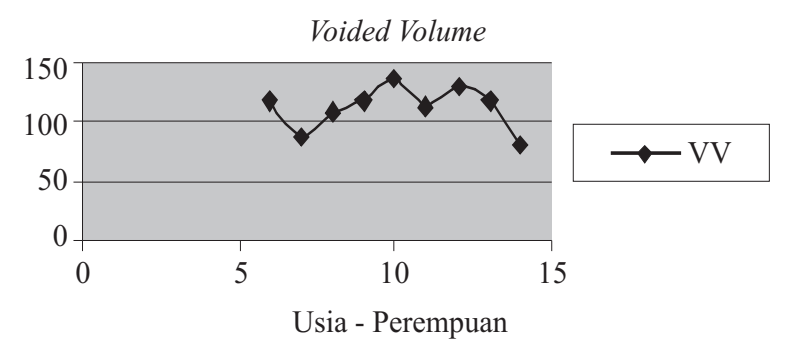

Gambar 6. Rerata voided volume pada masing-masing kelompok usia pada anak perempuan 
Tabel 5. $Q$ max, $Q$ ave, dan voided volume berdasarkan usia, tinggi, berat, BSA dan BMI pada anak laki-laki

\begin{tabular}{|c|c|c|c|c|}
\hline No & Regresi linear & $\begin{array}{c}\text { Root } \\
\text { Mean } \\
\text { Square } \\
\text { Error }\end{array}$ & $\begin{array}{l}\text { Ho : } \\
\text { slope } \\
=0 p\end{array}$ & Keterangan \\
\hline \multirow[t]{6}{*}{1} & $\mathrm{Q} \max =-8,534+0,176 \mathrm{~TB}$ & 0,118 & 0,000 & Significant \\
\hline & $\mathrm{Q} \max =8,080+0,212 \mathrm{BB}$ & 0,107 & 0,001 & Significant \\
\hline & $\mathrm{Q} \max =2,756+11,291 \mathrm{BSA}$ & 0,129 & 0,000 & Significant \\
\hline & $\mathrm{Q} \max =7,986+0,376 \mathrm{BMI}$ & 0,044 & 0,030 & Significant \\
\hline & $\mathrm{Q} \max =4,249+1,034$ usia & 0,120 & 0,001 & Significant \\
\hline & $\mathrm{Q} \max =2,283+0,151 \mathrm{VV}$ & 0,363 & 0,001 & Significant \\
\hline \multirow[t]{6}{*}{2} & $\mathrm{Q}$ ave $=-2,416+0,086 \mathrm{~TB}$ & 0,092 & 0,002 & Significant \\
\hline & $\mathrm{Q}$ ave $=5,703+0,101 \mathrm{BB}$ & 0,081 & 0,003 & Significant \\
\hline & $\mathrm{Q}$ ave $=3,134+5,418 \mathrm{BSA}$ & 0,099 & 0,001 & Significant \\
\hline & $\mathrm{Q}$ ave $=5,891+0,166 \mathrm{BMI}$ & 0,029 & 0,083 & Non Significant \\
\hline & $\mathrm{Q}$ ave $=4,010+0,480$ usia & 0,086 & 0,005 & Significant \\
\hline & $\mathrm{Q}$ ave $=1,809+0,114 \mathrm{VV}$ & 0,373 & 0,001 & Significant \\
\hline \multirow[t]{5}{*}{3} & $\mathrm{VV}=-29,878+1,001 \mathrm{~TB}$ & 0,029 & 0,080 & Non Significant \\
\hline & $\mathrm{VV}=68,483+1,076 \mathrm{BB}$ & 0,021 & 0,138 & Non Significant \\
\hline & $\mathrm{VV}=38,186+60,465 \mathrm{BSA}$ & 0,028 & 0,085 & Non Significant \\
\hline & $\mathrm{VV}=77,979+1,328 \mathrm{BMI}$ & 0,004 & 0,509 & Non Significant \\
\hline & $\mathrm{VV}=33,517+6,823$ usia & 0,209 & 0,032 & Significant \\
\hline TB & BMI & & & \\
\hline $\begin{array}{l}\text { BB } \\
\text { BSA }\end{array}$ & $\begin{array}{l}=\text { berat badan } \\
=\text { body surface }\end{array}$ & & & \\
\hline
\end{tabular}

Tabel 6. $Q$ max, $Q$ ave, dan voided volume berdasarkan usia, tinggi, berat, BSA, dan BMI pada anak perempuan

\begin{tabular}{|c|c|c|c|c|}
\hline No & Regresi linear & $\begin{array}{c}\text { Root } \\
\text { Mean } \\
\text { Square } \\
\text { Error }\end{array}$ & $\begin{array}{l}\text { Ho: } \\
\text { slope } \\
=0 p\end{array}$ & Keterangan \\
\hline \multirow[t]{6}{*}{1} & $2 \max =17,022-0,015 \mathrm{~TB}$ & 0,001 & 0,710 & Nol \\
\hline & $=15,489-0,017$ & 0,001 & 0,787 & \\
\hline & $=15,879-0,845 \mathrm{BSA}$ & 0,001 & 0,763 & Non $\mathrm{S}$ \\
\hline & $\mathrm{Q} \max =15,489-0,017 \mathrm{BMI}$ & 0,001 & 0,787 & Nor \\
\hline & $\mathrm{Q} \max =14,718+0,028$ usia & 0,000 & 0,911 & Non Significant \\
\hline & $\mathrm{Q} \max =2,401+0,136 \mathrm{VV}$ & 0,294 & 0,001 & Significant \\
\hline \multirow[t]{6}{*}{2} & $=10,0$ & 0,002 & 0,683 & \\
\hline & $\mathrm{Q}$ ave $=10,1$ & 0,015 & 0,211 & $\mathrm{No}$ \\
\hline & $\mathrm{Q}$ ave $=10,367-1,5$ & 0,009 & 0,350 & ificant \\
\hline & $\mathrm{Q}$ ave $=10,891-0,045 \mathrm{BMI}$ & 0,015 & 0,211 & lificant \\
\hline & $\mathrm{Q}$ ave $=8,715+0,003$ usia & 0,000 & 0,981 & Non Significant \\
\hline & $\mathrm{Q}$ ave $=1,707+0,116 \mathrm{VV}$ & 0,331 & 0,001 & Significant \\
\hline \multirow[t]{5}{*}{3} & $V V=109,883+0,039 \mathrm{~TB}$ & 0,000 & 0,931 & Non $\mathrm{Si}$ \\
\hline & $\mathrm{VV}=124,718-0,319 \mathrm{BB}$ & 0,002 & 0,632 & ificant \\
\hline & $\mathrm{VV}=122,569-7,150 \mathrm{BSA}$ & 0,001 & 0,815 & \\
\hline & $\mathrm{VV}=124,718-0,319 \mathrm{BMI}$ & 0,002 & 0,632 & \\
\hline & $\mathrm{VV}=33,509+13,937$ usia & 0,332 & 0,284 & ignifica \\
\hline
\end{tabular}

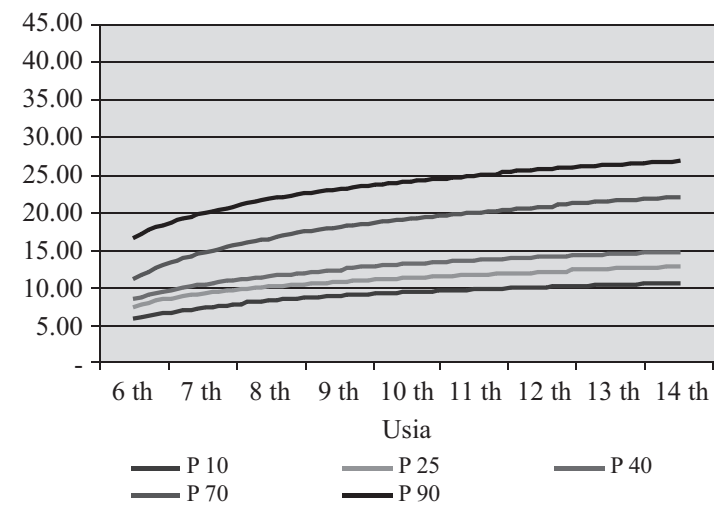

Gambar 7. Nomogram $Q$ max berdasarkan usia pada anak laki-laki

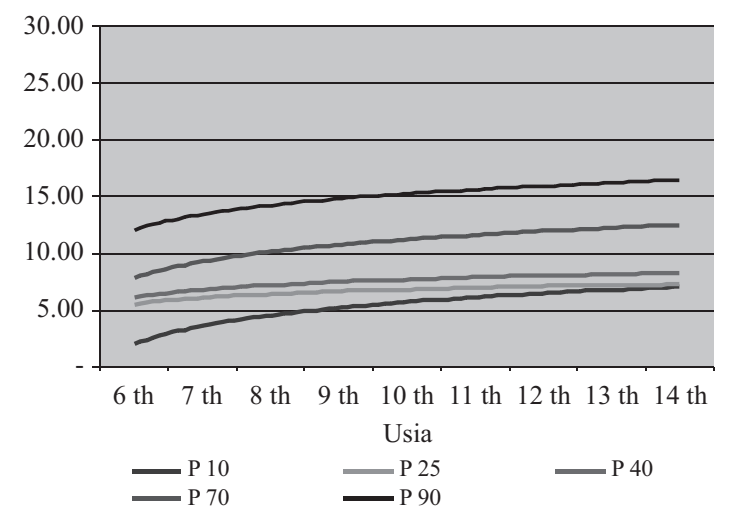

Gambar 8. Nomogram $Q$ ave berdasarkan usia pada anak laki-laki

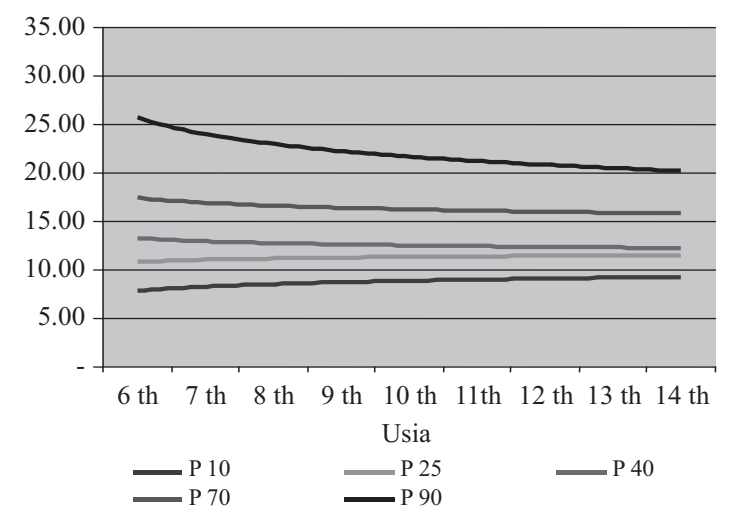

Gambar 9. Nomogram $Q$ max berdasarkan usia pada anak perempuan 


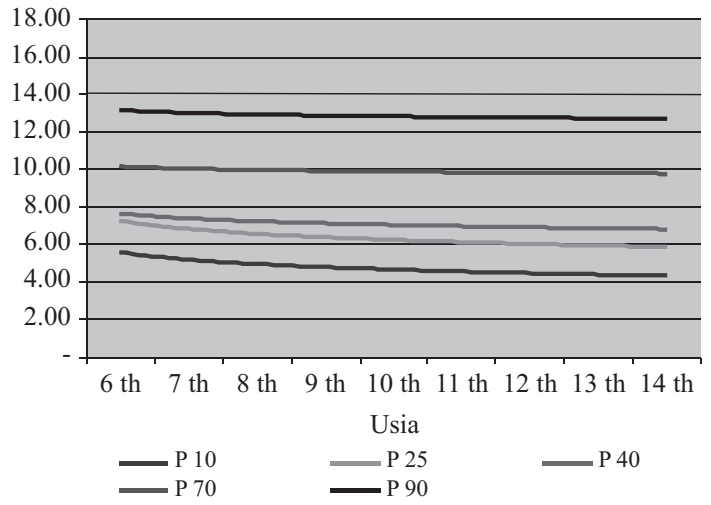

Gambar 10. Nomogram $Q$ ave berdasarkan usia pada anak perempuan

\section{DISKUSI}

Studi urodinamik merupakan investigasi dinamis yang dilakukan untuk merefleksikan status terkini traktus urinarius, dasar dari studi ini adalah informasi obyektif mengenai fungsi buli-buli dan uretra. ${ }^{1-9}$ Studi terhadap anak-anak pertama dilakukan pada awal tahun 1950 oleh Kaufman (1957). 1,3,4,8 Kapasitas buli-buli pada anak-anak relatif sulit dinilai akibat adanya proses perkembangan yang dinamis dan berbeda pada masing-masing anak. ${ }^{3}$ Pertanyaan mendasar adalah berapa rentang parameter fisiologis dari uroflowmetri anak-anak, ${ }^{1-3}$ dan berapa kapasitas normal buli-buli pada anak-anak untuk menilai fungsi traktus urinarius bagian bawah. ${ }^{3}$ Nilai kapasitas buli-buli fungsional berbeda dengan kapasitas maksimal bulibuli, nilai kapasitas buli-buli fungsional diperoleh berdasarkan volume berkemih, baik berdasarkan catatan pasien sendiri maupun pada saat dilakukan uroflowmetri, dan merefleksikan pengisian natural buli-buli. ${ }^{3}$

Pada penelitian ini ditemukan rerata $Q \max$ pada perempuan adalah $14,99 \pm 5,51 \mathrm{ml} /$ det dan pada laki-laki $14,45 \pm 7,21 \mathrm{ml} /$ det sedangkan rerata $Q$ ave pada perempuan adalah $8,75 \pm 3,25 \mathrm{ml} /$ det dan pada laki-laki 8,74 $\pm 3,95$ $\mathrm{ml} /$ det. Hal ini sesuai dengan penelitian Seo di Korea dan Miskole yang $Q \max$ dan $Q$ ave lebih tinggi pada perempuan. ${ }^{2,8}$ Adanya $Q \max$ dan $Q$ ave yang lebih tinggi pada perempuan ${ }_{1,6,10}$ kemungkinan berhubungan dengan uretra perempuan yang lebih pendek, beberapa faktor lainnya seperti kebiasaan toilet training, pola makanan dan minuman, dan sebagainya. ${ }^{1}$ Perbedaan rerata $Q \max$ dan $Q$ ave pada kedua jenis kelamin relatif kecil yaitu masing-masing $0,54 \mathrm{ml} /$ det dan $0,01 \mathrm{ml} / \mathrm{det}$ ( $\mathrm{p}=0,542$ untuk $Q \max$ dan 0,992 untuk $Q$ ave, tidak bermakna ). Abele dan Krepler melaporkan pancaran urin kedua jenis kelamin adalah relatif tidak berbedal sedangkan penelitian Matsson melaporkan perbedaan sebesar $2 \mathrm{ml} /$ detik pada $Q$ max anak-anak perempuan dibandingkan dengan laki-laki, dan $1,5 \mathrm{ml} /$ detik untuk $Q$-ave. ${ }^{5}$

Rerata voided volume pada perempuan adalah 115,04 $\pm 60,19 \mathrm{ml}$ dan pada laki-laki 100,78 $\pm 82,44 \mathrm{ml}$. Chrzan melaporkan bahwa voided volume pada perempuan lebih tinggi daripada laki-laki, namun tidak terdapat perbedaan bermakna pada volume residu. ${ }^{3}$ Jumlah voided volume ditentukan berdasarkan besarnya kapasitas fungsional buli-buli. Rumus penentuan kapasitas fungsional buli-buli yang paling sering digunakan adalah formula Koff, ${ }^{3}$ namun demikian untuk anak-anak di Asia yang kapasitas fungsional buli-bulinya ternyata lebih kecil daripada ras kaukasia, maka lebih tepat digunakan rumus sesuai penelitian Hamano dkk. (1999), yaitu : $25 \times($ umur(thn $))+2) .{ }^{11}$

Voided volume pada penelitian ini digunakan nilai batas bawah $20 \mathrm{ml}$ karena pada anak-anak terutama pada kelompok usia sangat kecil sulit mengenali kapan saatnya pengosongan buli-buli yang tepat. ${ }^{3}$ Treves menemukan korelasi antara kapasitas fungsional buli-buli dengan tinggi dan berat badan, ${ }^{3}$ namun demikian kapasitas buli-buli tidak merefleksikan parameter tubuh anak-anak, hanya dapat diperkirakan tetapi tidak dapat dikalkulasikan secara tepat, dan dibutuhkan studi lebih lanjut untuk menentukan formula kalkulasi yang akurat. $^{3}$

Pada penelitian ini ditemukan perbedaan antara anak lak-laki dan anak perempuan. Pada anak laki-laki ditemukan hubungan bermakna antara penambahan usia dengan $Q$ max dan $Q$ ave, sedangkan untuk anak perempuan, tidak dipengaruhi oleh usia. Hal ini merupakan kebalikan dari studi di Iran oleh Kajbafzadeh dkk. pada tahun 2005 yang menunjukkan bahwa pancaran urin pada perempuan mengalami peningkatan yang bermakna secara statistik seiring dengan usia, sedangkan tidak demikian halnya pada laki-laki. ${ }^{1,10}$

Pada anak laki-laki terdapat hubungan bermakna antara penambahan tinggi badan, berat badan, body surface area, dan body mass index terhadap $Q$ max. Demikian pula dengan $Q$ ave kecuali untuk body mass index. Untuk voided volume, semuanya tidak bermakna. Sedangkan untuk anak perempuan, tidak terdapat hubungan bermakna antara $Q \max , Q$ ave, dan voided volume dengan tinggi badan, berat badan, body surface area dan body mass index. Tinggi rendahnya $Q \max$ dan $Q$ ave, tidak dipengaruhi oleh usia. Baik pada anak laki-laki maupun anak perempuan, $Q$ max dan $Q$ ave mempunyai hubungan bermakna dengan voided volume. Scipio menemukan bahwa hanya terdapat korelasi lemah antara usia, tinggi badan, berat badan, dan body surface area terhadap $Q$ max dan $Q$ ave, ${ }^{1}$ sedangkan Segura (1997) dan Amaro (1996) melaporkan bahwa $Q$ max dan $Q$ ave meningkat sesuai dengan voided volume, usia, ${ }^{1,2,4,6,9}$ dan body surface area. ${ }^{2,9}$

\section{SIMPULAN}

Nomogram uroflowmetri dapat menjadi salah satu komponen diagnostik yang berguna dalam penemuan gangguan pancaran urin pada rentang voided volume yang bervariasi, uroflowmetri dapat menjadi skrining awal pada gangguan berkemih pada anak-anak. Adanya perbedaan nilai dengan beberapa penelitian yang telah dilakukan 
sebelumnya disebabkan karena beberapa faktor seperti perbedaan faktor demografis, sosial budaya, pola perilaku berkemih, dan lain-lain. Penelitian ini memberikan nilai referensi untuk nilai pancaran maksimum dan nilai pancaran rata-rata urin pada anak-anak laki-laki dan perempuan normal. Walaupun demikian masih diperlukan penelitian lanjutan dengan jumlah sampel yang lebih banyak

\section{UCAPAN TERIMAKASIH}

Penulis mengucapkan terima kasih kepada Dr Boyke Sumantri SpU atas bantuan alat uroflowmetri, Bpk H. Sudjadi Purwosaputro SE atas bimbingan statistik dan pembuatan nomogram, staf Poliklinik Khusus Urologi RSCM, SD/SMP Yayasan Advent III Menteng Jakarta Pusat, Yayasan Rumah Belajar Jakarta Pusat serta berbagai pihak yang tidak dapat disebutkan satu persatu atas bantuan dan kerjasamanya hingga makalah ini dapat diselesaikan dengan baik.

\section{DAFTAR PUSTAKA}

1. Kajbafzadeh AM, Yazdi CA, Rouhi O, Tajik P,Mohseni P. Uroflowmetry nomogram in Iranian children aged 7-14 years. BMC Urol. 2005; 5: 3.

2. Gutierrez Segura C. Urine flow in childhood: a study of flow chart parameters based on 1361 uroflowmetry test. J Urol. 1997;
157(4):1426-8.

3. Chrzan R, Czernik J, Apoznanski W, Baglaj M, Patkowkski D. Assessing bladder capacity in children: Is it feasible at all? Neurourol Urodynam. 2006; 25: 211-4.

4. Gaum LD, Wese FX, Liu TP, Wong AK, Hardy BE, Churchill BM. Age related flow rates nomograms in a normal pediatric population. Acta Urol Belg. 1989; 57(2): 457-66.

5. Matsson S, Spangberg A. Flowrate nomograms in 7-16 year-old healthy children. Neurourol Urodyn.1994; 13(3): 267-80.

6. Pompino HJ, Hoffmann D. Normal urinary flow for girls aged 3-14 years. Kinderchir Z. 1983; 38(3): 177-81.

7. Jensen KM, Nielsen KK, Jensen H, Pedersen OS, Krarup T. Urinary flow studies in normal kindergarten and schoolchildren. Scan J Urol Nephrol. 1983; 17(1):11-21.

8. Seo CW, Park JS. Analysis of urinary flow in 577 normal children. KM Base. 2000; 41(7): 850-5.

9. Amaro JL, Trindade Filho JC, Vercesi LA, Agostinho AD, Goldberg J, Trindade JC. Urinary flow in children : correlation with age, body height and body surface area. J Urol (Paris). 1996; 102(2): 85-6.

10. Haylen BT, Ashby D, Sutherst JR, Frazer MI, West CR. Maximum and average urine flow rates in normal male and female populations--the Liverpool nomograms. Br J Urol. 1989; 64(1): 30-8.

11. Hamano S, Yamanishi T, Igarashi T, Murakami S, Ito H. Evaluation of functional bladder capacity in Japanese children. Int J Urol. 1999; 6(5): 226-8. 